\title{
JUDICIAL PRONOUNCEMENT ON WOMEN CRIME VICTIMS IN INDIA: A CRITICAL STUDY
}

\author{
Anuradha Singh, (Research Scholar) \\ Jiwaji University Gwalior, Madhya Pradesh, India, \\ ORCID: https://orcid.org/0000-0002-1672-8931 \\ Email: anuradhasinghadvocate@gmail.com
}

\author{
Electronic version \\ URL: http://www.researchinspiration.com \\ DOI: https://doi.org/10.53724/inspiration/v6n2.03 \\ ISSN: 2455-443X \\ Vol. 6, Issue-II, March 2021 \\ Page No. 08- 12 \\ Publisher \\ Welfare Universe
}

Electronic reference/Article is to be Cited:

Anuradha Singh, (2021). Judicial Pronouncement on Women Crime Victims in India: A Critical Study. Research Inspiration: An International Multidisciplinary e-Journal, ISSN 2456-443X, 6(II), 08-12. https://doi.org/10.53724/inspiration/v6n2.03

CResearch Inspiration: An International Multidisciplinary e-Journal 2021. This Open Access article is published under a Creative Commons Attribution Non-Commercial 4.0 International License https://creativecommons.org/licenses/by-nc/4.0/, which permits non-commercial reuse, distribution, and reproduction in any medium, provided the original work is properly cited. For citation use the DOI. For commercial re-use, please contact editor email:- publish1257@gmail.com By accessing the work you hereby accept the Terms. Non-commercial uses of the work are permitted without any further permission from Research Inspiration: An International Multidisciplinary eJournal provided the work is properly attributed.

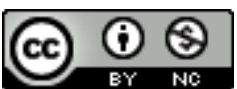

This work is licensed under a Creative Commons Attribution-NonCommercial 4.0 International License. 


\title{
JUDICIAL PRONOUNCEMENT ON WOMEN CRIME VICTIMS IN INDIA: A CRITICAL STUDY
}

\author{
Anuradha Singh, (Research Scholar) \\ Jiwaji University Gwalior, Madhya Pradesh, India, \\ ORCID: https://orcid.org/0000-0002-1672-8931 \\ Email: anuradhasinghadvocate@gmail.com
}

\begin{abstract}
In India the Constitution makers were aware of the discrimination women faced in the society. Preamble is the soul of the Constitution it provides equality of status and opportunities to women. Judiciary reflected it's mind through judgment. In series of judgments Judiciary have categorically stated there is discrimination prevailing and the women are facing bias and prejudice in the society. Supreme Court of India struck down the discriminatory policies and attitude of society in the series of judgments and also directed the legislature to form laws to protect women. It is the Vishakha guidelines which led to The Sexual Harassment of Women at Workplace (Prevention, Prohibition and Redressal) Act, 2013. Supreme Court states it is the duty of the government to protect the life and dignity No individual or group has the right to interfere in a consensual and legal relationship between two adults the court opined in Nitish Katara Case. The Central government stated before the court it was consulting with states to draft a law against honour killings.
\end{abstract}

Keywords: Discrimination, Bias, Prejudice women faced in the society.

\section{Introduction}

The Indian society is a patriarchal society. The women were confined to do the household work they had no say in the decision making and property was not usually given in inheritance to them. Though the Constitution grated equality of status and of opportunities but the society's discriminatory attitude prevailed.

To see the status of crime against women the socio-legal aspect need to be taken in account. According to Sarah M Grimke "All history asserts that man has subjugated women to his will, used her as a means to promote his self-gratification, to minister to his sexual pleasures, to be instrumental in promoting his conform; but never has he desired to elevate her to that rank she was created to fill. He has done all he could to debase and enslave her mind and now he looks triumphantly on the ruin he has wrought, and says, the being he has thus deeply injured in his inferior .But I ask no favour for my sex, ......All I ask our brethren in, that they will take their feet off from our necks and permit us to stand upright on that ground which God designed us to occupy.",

According to ancient Indian sage Manu view "women to be in eternal bondage." "Girls are supposed to be in the custody of their father when they are child, women must be under the custody of their husband when married and under the custody of her son as widows. In no circumstances is she was allowed to

\footnotetext{
${ }^{1}$ Sarah M. Grimke, letter on the equality of sexes and the conditions of women, Boston Iraac Kanapp 1838. www.digitalhistory.uh.edu
} 
assert herself independently". ${ }^{2}$

\section{Pre Independence era}

Pre Independence era in the British period the position of women changed due to western influence. The first legislation was passed in 1860 under which the minimum age for consummation of marriage in the case of girls was raised to ten.

In 1891, the age of consent for girls was raised to twelve years and in 1925 to thirteen years for married girls and fourteen years for unmarried ones. In 1929, the Child Marriage Restraint Act (Sharda Bill) was passed. Under this Act, which came into being in 1930, the minimum age of marriage for a girl was fixed at fourteen years and for a boy at eighteen years. Due to the efforts of Raja Ram Mohan Roy to ban evil practice of Sati (widow sacrifices herself by sitting atop her deceased husband's funeral pyre). Lord William Bentick, the Governor General of India passed a Sati Regulation XVII A.D. 1829 of the Bengal Code. $^{3}$

Post-Independence The Constitution provides equality to all it's citizens Article 14 Equality before law, Fundamental Rights, Fundamental Duties, Directive Principal of State Policy. It provides special provisions for the development of women in every sphere of life. The Fundamental Duties were added to the Constitution by the 42nd Amendment in 1976 it is the duty of citizens of India to renounce practice derogatory towards women. ${ }^{4}$

\section{Judicial Pronouncements}

In K Ramamaswaray in Madhu Keshav Vs. State of Bihar ${ }^{5}$ Apex Court opined Women have always been discriminated against men and suffered denial and are suffering discrimination in silence. Women are suffering of inequalities indignities and discrimination in all walks of life.

In Maneka Gandhi Vs. Union of India ${ }^{6}$ Apex Court opined The original Constitution of India did not reflect concerns of gender justice adequately. It provides discrimination on the ground of sex but it did not take note of discrimination that is based on gender. Giving women certain rights in order to compensate them for their reproductive function, it is not charity but an obligation Article 15(3) of Constitution of India reads that the State may make special provisions for women. This is to protectionist strategy towards women so they can further their advancement.

In Dimple Singh Vs. Union of India ${ }^{7}$ The Delhi High Court expressed it's apprehension that unless attitude change, elimination of discrimination against women is hard cannot be achieved. It is the patriarchal mindset needs to be change. It appears that there is st5ill a lurking doubt about capabilities of lady officers.

In C.B. Mutumma Vs. Union of India ${ }^{8}$ Apex Court held in a writ petition which was filed by Mutumma a senior member of Indian Foreign Service, complained that she has been denied promotion to Grade I illegally and unconstitutionally. She pointed out that various rules of the civil service were discriminatory against women. The Supreme Court through Justice V.R. Krishna Iyer and P.N. Singhal held that the writ petition filed by Mutumma senior member of Indian Foreign Service, bespeaks a story whether Article 14

\footnotetext{
2 Alteker, A.S., The position of women in Hindu Civilization, Motilal Banarsidas Publishers Banaras, 1962 ,

${ }^{3}$ Sati Abolition [December 4, 1829] This Day in History: https://byjus.com/free-ias-prep/this-day-in-history-dec04/ (25th March 2021)

${ }^{4}$ Article 51-A (e), $42^{\text {nd }}$ Amendment 1976.

5 (1966) 5 SCC 148

${ }^{6}$ AIR 1978 SC 597.

7 (2001)DLT917.

${ }^{8}$ (1979)4SSC 260
} 
of the Constitutional mandate shall not be shaken by governmental action or inaction but it is the effect of the grievance of Mutumma that sex prejudice against Indian women hood pervades the service rules even a third of a century after freedom .if high officials loose hopes of equal justice under the rules, the legal lot of the little Indians, already priced out of the expensive judicial market, is best left to guess". It mocked on the government to not applying the principle of Article 14 of the constitution in practice.

In Air India Vs. Nargesh Meerza ${ }^{9}$ Apex Court opined "an air hostess should not marry before the completion of four years of service" the court held " it was a sound and salutary provision apart from improving the health of the employee it helps a great deal in the promotion and boosting up of our family planning programme.". The Apex Court in this case struck down the air India Regulations relating to retirement and the pregnancy bar on service of air hostesses as unconstitutional on the ground that the conditions laid down therein are unreasonable and arbitrary. Supreme Court criticize the prejudice towards women employees not tolerable.

In Neena Mathur Vs. LIC $^{10}$ Apex Court opined the Court recognized that privacy was an important aspect of personal liberty. The Apex Court was shocked to see that LIC questionnaire sought information about the dates of menstrual periods and past pregnancies, and the petitioner was terminated for not providing correct information to the LIC. The Apex Court held the questionnaire amounted to the invasion of privacy and that therefore such probes could not be made. The right to personal liberty guaranteed under Article 21 included the right to privacy which is of pivotal importance. Women have a fundamental right to personal liberty and live with dignity.

In Zahida begum Vs. Mustaque Ahmad ${ }^{11}$ Apex Court opined a suit was filed by the wife for dissolution of marriage on the ground of impotency of husband who was unable to perform marital obligation. On the contrary he requested that the Court that wife be directed to undergo medical checkup so as to ascertain her virginity. Karnataka high court held that the direction of the trial court to the wife to undergo virginity test was improper and invaded the privacy of wife and violation of Article 21 of the constitution. The constitution of India granted right to personal liberty in Article 21 of the constitution and the women cannot be deprived of it.

In Bhagwan Das Vs. State (NCT) of Delhi ${ }^{12}$ Apex Court opined in this the petitioner was infuriated with his daughter for having dishonored his family since she had left her husband and was living in an incestuous relationship with her uncle. Hence he strangulated her to death. Justice Markandey Katju and Gyan Sudha Mishra held there is nothing honorable in honour killings and they are nothing but barbaric and brutal murders by bigoted persons with feudal minds. In our opinion honour killings for whatever reasons come within the category of rarest of rare cases deserving death punishment........All the persons who are planning to perpetrate, honour killings should know that the gallows await them". Honour killings are the brutal murders which shames the humanity.

In Lata Singh Vs. State of U.P. and Anr ${ }^{13}$ Apex Court opined that "this is wholly illegal, if someone is not happy with the behaviour of his daughter or other person, who is his relation or of his caste, the

${ }^{9}$ (1981) 4 SCC 335

${ }^{10}(2008) 3$ SCC 1.

${ }^{11}$ AIR (2006) Kant 10., ILR 2005, 4185.

${ }^{12}$ AIR 2011 SC 1863.

${ }^{13}$ (2006) 5 SCC 475 
maximum he can do is to cut off social relations with her/him, but he cannot take the law into his own hands by committing violence or giving threats of violence". The violence against women is not tolerable in India.

In Shayara Bano Vs. Union of India ${ }^{14}$ Apex Court opined Shayra Bano was married to Rizwan Ahmed for 15 years, in 2016 he divorced her through instantaneous triple talaq. The Supreme Court Constitutional Bench held that the practice of instantaneous triple talaq is unconstitutional. Treating women like a doormat is not fair.

In Vineeta Sharma Vs. Rakesh Sharma and Ors ${ }^{15}$ Apex Court affirmed the equal rights of daughters to coparcenary property. Supreme Court clarified that irrespective of coparcener father being alive or not on or before the Hindu Succession Amendment Act 2005 a daughter would be entitled to a share in coparcenary property in the same manner as a son simply by virtue of (1) her birth and (2) her being alive as on date of coming into force of the 2005 amendment. This Succession Amendment Act 2005 grant daughter a share in the family property.

In Secretary Ministry of Defence Vs. Babita Puniya \& Ors ${ }^{16}$ Apex Court affirmed, A two-judge SC bench of Justices DY Chandrachud and MR Shah held a critical note of the need to change mindsets about gender stereotypes that view women as the weaker sex, while re-affirming the Delhi High Court's 2010 ruling to allow the grant of Permanent Commission to Women Short Service Commission Officers on par with their male counterparts.

\section{Conclusion}

The laws are pronounced by the Judge .The Supreme Court in series of judgment held that there is a discriminatory attitude towards women prevailing in the society and this attitude requires to be changed to make a gender equal society. Supreme Court struck down various prejudice norms and behaviours of the society in the judgments. The legislation created several new laws and made amendment to remove the hindrance faced by women. It is the duty of the citizens to treat women with equality.

\section{Suggestion}

Despite the constitution safeguards to treat women equally and the large number of laws prevailing to provide protective shield to women still women are not treated at par with men. The way to make women equal by giving them equal access to education and opportunities for career advancement to women. For this society has to change the mindset and treat women as equal partners.

\footnotetext{
$* * * * * * * * * * * * * * * * * * * * * * * * * * *$
}

${ }^{14}$ (2017) 9 SCC 1.

${ }^{15}$ Civil Appeal (s) 32601/18.

${ }^{16}$ Source SLP 1127-1128/2013. 